\title{
Whole-farm nutrient balances are an important tool for California dairy farms
}

by Alejandro R. Castillo

In terms of nutrient balances, modern dairy systems are more complex than ever before. Feed is the primary nutrient input on the average California dairy farm. Whole-farm nutrient balances are an important tool for evaluating the economic and physical viability of each dairy farm, improving nitrogen imbalances and complying with environmental regulations. This article discusses the concept of nutrient balances and variables affecting the improvement of nitrogen imbalances in California dairy systems.

IN May 2007, California's Central Valley Regional Water Quality Control Board (Region 5) adopted new regulatory waste-discharge requirements for all existing and new milk-cow dairies in the Central Valley (CRWQCB 2007). Dairy farmers were required to complete and submit an existing conditions report and preliminary dairy facility assessment (PDFA) by Dec. 31, 2007. This includes a complete description of the dairy facility and an estimation of major sources of nutrients potentially present to apply to cropland. They are required to include a waste management plan (WMP) to control dry manure and wastewater, and an annual nutrient management plan (NMP).

The WMP and NMP will be important objectives for California dairy producers in the coming years. According to the WMP requirements for each dairy, producers must be prepared with sufficient storage capacity to contain all the manure that their dairy produces, to avoid illegal discharges on or off site. They must also be prepared to apply manure according to an NMP based on the chemical composition of their manure and soil, as well as crop requirements.

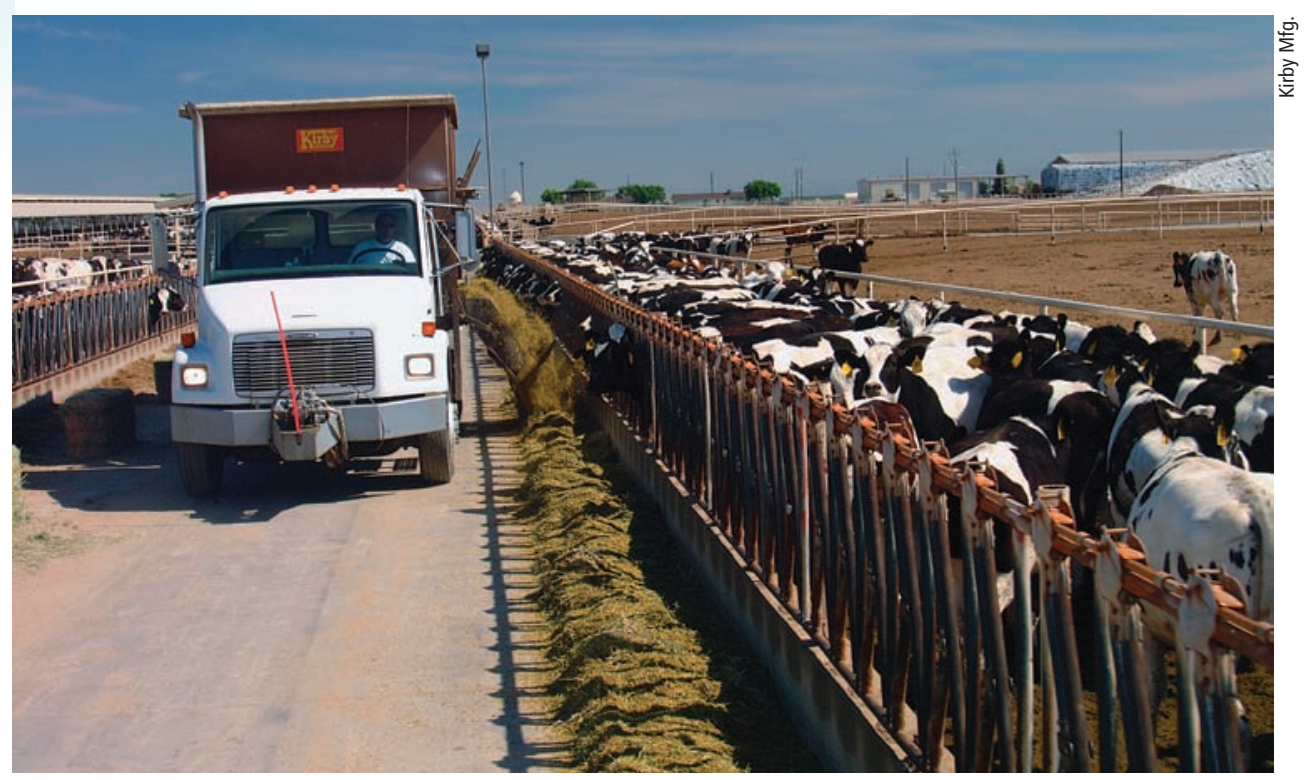

Dairy operations in California are becoming more concentrated, with more cows, more milk produced per cow, and more feed purchased off-farm. In order to limit pollution from nutrientladen runoff, California dairies in the Central Valley face new water-quality-related rules.

Modern dairy farms are more complex than ever before. They have become more concentrated in recent years, with cows producing more milk, and more feed purchased from off-farm sources. Feed is the primary nutrient input into the average California dairy farm. Improving the efficiency of nutrient utilization presents important economic and environmental challenges. The relationship between nutrient balances and how nutrients are utilized on the farm is not well understood. This article discusses the concept of "nutrient balances" and variables affecting the improvement of nitrogen imbalances in California dairy systems. Nitrogen from different industries is an important pollutant of California air and waterways.

\section{Whole-farm nutrient balances}

A whole-farm nutrient balance can be defined as the difference between farm nutrient imports and exports; it provides a general indicator of whether a farm is at risk of building up nutrients and releasing them into the environment. The quantification of these losses can be used as an indicator of air, soil and underground water contamination. Imbalances represent the quantity of direct losses (such as ammonia volatiliza- tion) or increased nutrient inventories in soil and groundwater (such as salts and nitrate leaching) (fig. 1). The three primary components that must be integrated are nutrient imports, nutrient exports and the dairy facility itself.

Software can be used to calculate nutrient balances, with information generated by dairy operators and/or private consultants. UC Cooperative Extension, the California Dairy Quality Assurance Program, regulatory agencies and the dairy industry are assisting dairy producers with educational programs to understand and comply with the new regulations.

On a normal dairy farm, nutrient imports and exports are highly diverse and variable, influenced by factors such as season, on-farm crops grown, forage availability, commodity prices and availability, and calving periods. Consequently, producers should use a minimum of 1 year to estimate a wholefarm nutrient balance, and maintain on-site records for 5 years. A recent study concluded that improvements to data collection methods for whole-farm nutrient balances will require increased skills and training for farmers and those assisting them in on-farm data collection and analysis (Powell et al. 2006). 


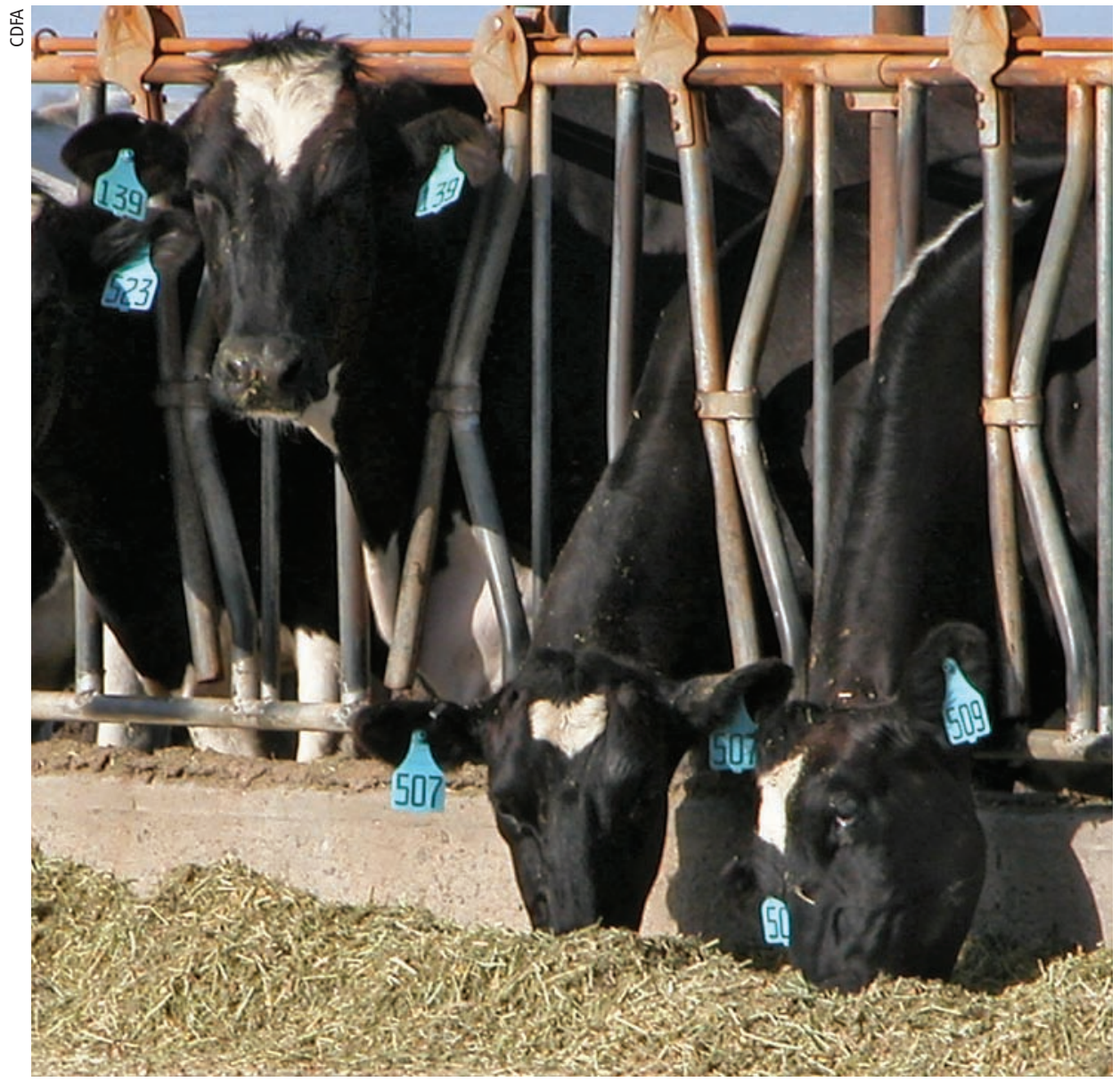

By calculating nutrient balances for the whole dairy operation, operators can improve feed efficiency and protect water quality. More-efficient cropping practices on dairies that grow their own silage and hay, as well as manure management, are important strategies.

In addition to the whole-farm nutrient balance previously discussed, two additional balances can be estimated: (1) when diets are adjusted according to animal requirements and (2) when manure is applied to the soil according to crop requirements (fig. 1). In both cases, nitrogen is one of the most studied nutrients used to estimate whole-farm nutrient balances.

\section{Nitrogen utilization}

Rasmussen et al. (2006) analyzed nutrient balances from 38 dairy and beef farms in New York, and found that there are currently no benchmarks to measure a livestock farm's nutrient management performance. They suggested several indicators that include: the quantity of nutrients imported, exported and remaining; nutrients remaining per animal unit; percentage of nutrients remaining; distribution of farm imports and exports; crop sales; and percentage of farm-produced forage and feed.

\section{Most studies that estimate whole-} farm nitrogen utilization express balances as a proportion. For example, Koelsch (2005) reviewed information from different dairy whole-farm balances in the United States, and found imbalances or direct losses of nitrogen value ranging from $59 \%$ to $84 \%$. Researchers from Cornell University did whole-farm balances on 24 dairy farms in northern New York, and the average nitrogen remaining (importsto-exports) was $46 \%$ (Larry E. Chase, Professor, Cornell University, personal communication). Castillo et al. (2000) analyzed information on whole-farm nitrogen balances from European dairy farms, including high and low nitrogen inputs, and estimated that harvested nitrogen in the outputs ranged from $44 \%$ to $84 \%$. Likewise, Spears et al. (2003) found that in whole-farm nitrogen balances carried out on 41 Western dairy farms, on average $36 \%$ of the inputs were accounted for in the outputs.

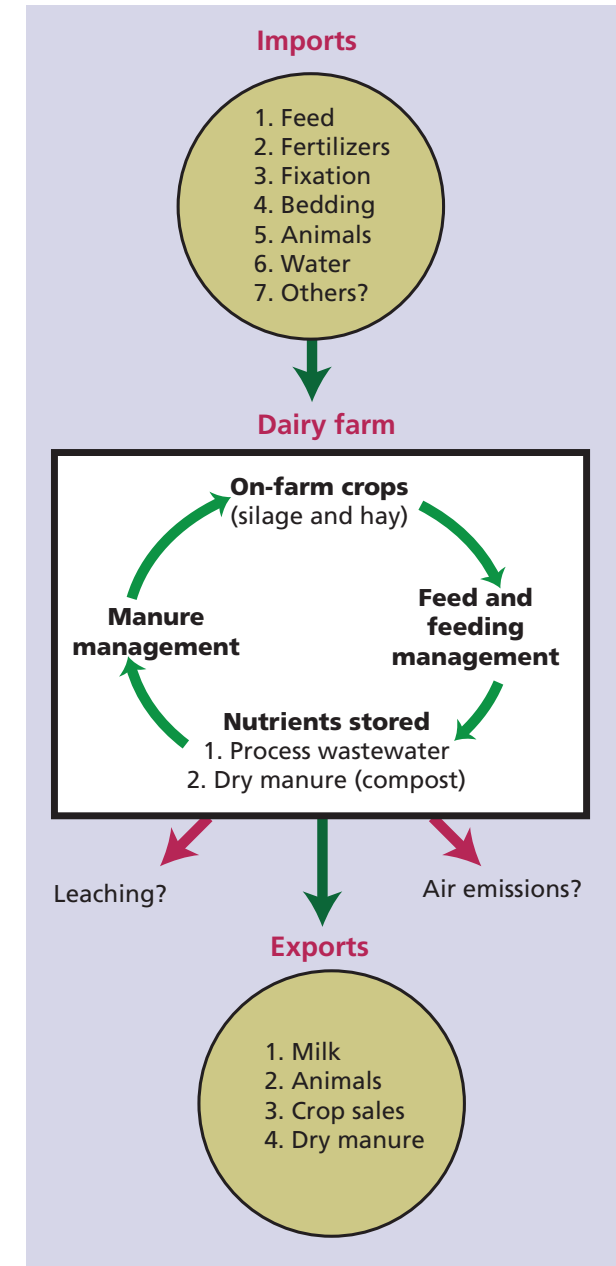

Fig. 1. A whole-farm nutrient balance.

All the research cited was carried out with different methodologies and situations. No scientific information has been produced specifically for California dairy systems to indicate an average or an optimal value for the efficiency of whole-farm nitrogen utilization.

\section{Adjusting nitrogen balances}

Strategies to improve nitrogen utilization include decreasing inputs, increasing outputs, or both. In practical terms, if the objective is to maintain the number of animals and acres, reduce inputs and/or increase outputs, improvements should be based on (1) the efficiency of feed and feeding management and (2) manure management practices.

The following examples, based on Spears et al. (2003) (table 1), analyzed the impact of several strategies to improve average nitrogen balances and present achievable goals for California dairies. 
Whole-farm nutrient balances provide a general indicator of whether a farm is at risk of building up nutrients and releasing them into the environment.

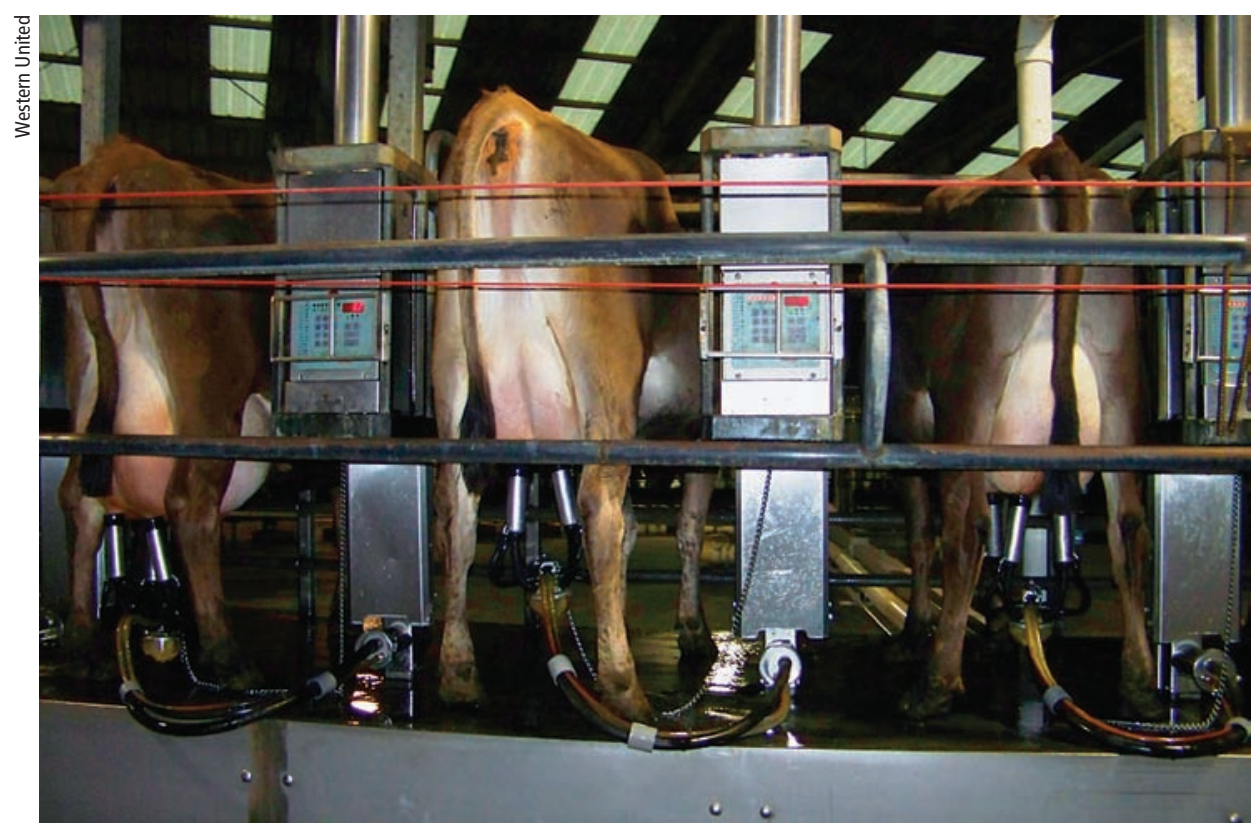

Increasing milk yield per cow and milk nitrogen output are additional strategies for managing nutrients on dairies. Above, Jersey cows are milked twice a day at the Hilarides Dairy in Lindsay, Calif.

Decreasing inputs $\mathbf{2 0} \%$. To decrease nitrogen inputs by $20 \%$, nitrogen intake in feed by dairy cows could be reduced by $10 \%$ (NRC 2001; Broderick 2003; Olmos Colmenero and Broderick 2006) and the on-farm growing of crops that take up nitrogen could be increased by $10 \%$. To this end, UC Cooperative Extension researchers are currently evaluating on-farm data using triplecropping on a minimum tillage system.

Increasing outputs $\mathbf{2 0 \%}$. Increasing milk output and the resulting levels of nitrogen in the milk was estimated to increase the nitrogen output to 5 tons per year, which may be obtained by increasing milk yields by about $10 \%$ (Wang et al. 2000). Also, to increase outputs by $20 \%$, it would be necessary to increase the export of nitrogen in manure from 15.5 to 19 tons per year.

Reducing nitrogen intakes and increasing crop production - thereby increasing the nitrogen harvested (see total inputs, fig. 1) represented more than $70 \%$ of the total nitrogen-balance improvements, estimated as tons nitrogen per year per dairy (126-101/81-47 = $0.74)$. Increasing milk yields per cow by $10 \%$ and manure nitrogen exports by
3.5 tons per year are important efforts (see total outputs, fig. 1), but they represent a lower proportion (less than 30\%) of the total nitrogen-balance improvement $(54-45 / 81-47=0.26)$.

\section{Dairy farm strategies}

Whole-farm nutrient balances are an important tool for understanding and evaluating the economic and physical viability of each dairy farm, improving nitrogen imbalances and complying with environmental regulations. Strategies to improve nitrogen balances for the average California dairy farm include adjusting diets according to animal requirements in order to decrease nitrogen import in feed, increasing onfarm crop production and milk yields per cow per day, and exporting manure to cropping and/or other production systems.

\footnotetext{
A.R. Castillo is Dairy Science Farm Advisor, UC Cooperative Extension, Merced County. The author thanks Larry E. Chase, Department of Animal Science, Cornell University, Ithaca, N.Y.; and Ron Rowe, Division of Environmental Health, Merced County.
}

\begin{tabular}{|c|c|c|}
\hline \multicolumn{3}{|c|}{$\begin{array}{l}\text { TABLE 1. Improving whole-farm nitrogen (N) } \\
\text { balances }\end{array}$} \\
\hline & $\begin{array}{l}\text { Spears et } \\
\text { al. (2003) }\end{array}$ & $\begin{array}{l}\text { Improved } \\
\mathrm{N} \text { balance }\end{array}$ \\
\hline & \multicolumn{2}{|c|}{$\begin{array}{l}\text { tons nitrogen per year } \\
\text { per dairy farm }\end{array}$} \\
\hline Total inputs & 126 & $101(-20 \%)$ \\
\hline Feed & 106 & 81 * \\
\hline Fertilizer & 5 & 5 \\
\hline Bedding & 1.3 & 1.3 \\
\hline Animals & 1 & 1 \\
\hline Fixation & 13 & 13 \\
\hline Total outputs & 45 & $54(+20 \%)$ \\
\hline Animal products & 28.5 & $34 t$ \\
\hline Crops & 1.0 & 1 \\
\hline Dry manure & 15.5 & $19 \ddagger$ \\
\hline $\begin{array}{l}\text { Balance (tons/ } \\
\text { year) }\end{array}$ & 81 & 47 \\
\hline Balance (\%) & 36 & 53 \\
\hline \multicolumn{3}{|c|}{$\begin{array}{l}\text { * Reduce nitrogen imports in feed by } 20 \% \text {, by increasing } \mathrm{cr} \\
\text { uptake } 10 \% \text { and restricting nitrogen in the diet } 10 \% \text {. } \\
\text { † Increase nitrogen in animal products by } 5.5 \text { tons per yr. } \\
\text { ₹ Increase exported manure nitrogen by } 3.5 \text { tons per yr. }\end{array}$} \\
\hline
\end{tabular}

\section{References}

Broderick GA. 2003. Effects of varying dietary protein and energy levels on the production of lactating dairy cows. J Dairy Sci 86:1370-81.

[CRWQCB] California Regional Water Quality Control Board. 2007. Waste Discharge Requirements General Order for Existing Milking Cow Dairies. Order No R5-2007-0035. May 2007. 125 p.

Castillo AR, Kebreab E, Beever DE, France J. 2000. $A$ review of efficiency of nitrogen utilization in dairy cows and its relationship with environmental pollution. J Anim Feed Sci 9:1-32.

Koelsch R. 2005. Evaluating livestock system environmental performance with whole-farm nutrient balance. J Environ Qual 34:149-55.

[NRC] National Research Council. 2001. Nutrient Requirements of Dairy Cattle (7th rev. ed.). Washington, DC: Nat Acad Pr. 381 p.

Olmos Colmenero JJ, Broderick GA. 2006. Effect of dietary crude protein concentration on milk production and nitrogen utilization in lactating dairy cows. J Dairy Sci 89:1704-12

Powell JM, Jackson-Smith DB, McCrory DF, Mariola M. 2006. Validation of feed and manure data collected on Wisconsin dairy farms. J Dairy Sci 89:2268-78

Rasmussen C, Ketterings Q, Albrecht G, et al. 2006 Mass nutrient balances - a management tool for New York dairy and livestock farms. In: Proc Silage Dairy Farming Conference. NRAES-181 Cooperative Extension, Ithaca, NY.

Spears, RA, Kohn RA, Young AJ. 2003. Whole-farm nitrogen balance on Western dairy farms. J Dairy Sci 86:4178-86.

Wang, SJ, Fox DG, Cherney DJR, et al. 2000. Whole herd optimization with the Cornell net carbohydrate and protein system. III. Application of an optimization model to evaluate alternatives to reduce nitrogen and phosphorus mass balance. J Dairy Sci 83:2160-9. 